\section{Protective role of curcumin against the toxic effects of cyclophosphamide in the third instar larvae of transgenic Drosophila melanogaster (hsp70-lacZ)Bg9}

Yasir Hasan Siddique

Drosophila Transgenic Laboratory, Section of Genetics, Department of Zoology, Faculty of Life Sciences, Aligarh Muslim University, Aligarh, India

\section{Abstract}

In the present study the effects of curcumin was studied against the toxic effects induced by 0.025 and $0.050 \mu \mathrm{L} / \mathrm{ml}$ of cyclophosphamide (CP) in the third instar larvae of transgenic Drosophila melanogaster (hsp70-lacZ)Bg9 using $h s p 70$ expression and dye exclusion test as a parameter. The exposure of the third instar larvae to $0.025 \mu \mathrm{L} / \mathrm{mL}$ of $\mathrm{CP}$ along with 1 , 5 and $10 \mu \mathrm{g} / \mathrm{mL}$ of curcumin results in the dose dependent significant decrease in the $h s p 70$ expression and tissue damage for 12,24 and 48 $h$ of duration. Similar results were obtained with the exposure of third instar larvae to $0.050 \mu \mathrm{L} / \mathrm{mL}$ of $\mathrm{CP}$ along with 1,5 and 10 $\mu \mathrm{g} / \mathrm{mL}$ of curcumin. The selected doses of curcumin i.e. 1,5 and $10 \mu \mathrm{g} / \mathrm{mL}$ were not toxic but reduced significantly the expression of $h s p 70$ and tissue damage induced by $\mathrm{CP}$. The results of the present study suggest that the curcumin has a protective role against the toxic effects of $\mathrm{CP}$ in the third instar larvae of transgenic Drosophila melanogaster (hsp70-lacZ)Bg ${ }^{9}$.

\section{Introduction}

Cyclophosphamide (CP) is an alkylating agent. ${ }^{1}$ It is used as a chemotherapeutic agent to treat various forms of leukemia, ${ }^{2}$ tumors, ${ }^{3}$ rheumatoid arthritis, ${ }^{4}$ and Wegner's granulomatosis. ${ }^{5}$ All living organisms under stressful condition respond by synthesizing heat shock proteins (HSPs). ${ }^{6,7}$ In the recent years, $h s p 70$ has been considered to be one of the candidate genes for predicting the cytotoxicity against environmental chemicals. ${ }^{8}-10$ Curcumin is the active ingredient of tumeric plant (Curcuma longa Linn., Zingiberaceae). ${ }^{11}$ It has been reported to possess antimutagenic, anticarcinogenic, antigenotoxic, antioxidant, antitumor, anti-inflammatory properties in different tests systems.12-16 Now-a-days the use of animals in toxicological/pharmacological research and testing has become an important issue for both science and ethics. As a result the emphasis has been given to the use of alternative to mammals in testing, research and education. ${ }^{17}$ The European Centre for the validation of Alternative Methods (EVCAM) has recommended the use of Drosophila as an alternative model for scientific studies. ${ }^{18}$ In our earlier study the effect of CP was studied for the hsp70 expression at $0.0025,0.025,0.050,0.10$ and $1.0 \mu \mathrm{L} / \mathrm{mL}$ in the third instar larvae of transgenic D. melanogaster (hsp70-lacZ)Bg9 and was found to increase hsp70 expression significantly as compared to the untreated at $0.025,0.050$ and $0.10 \mu \mathrm{L} / \mathrm{mL}^{19}$ In the present study an attempt has been made to validate this model for the evaluation of the natural plant products for their protective action. In the present study the effect of curcumin was studied against the toxic effects of $\mathrm{CP}$ in the third instar larvae of transgenic $D$. melanogaster (hsp70-lacZ)Bg9.

\section{Materials and Methods}

\section{Fly strain}

A transgenic Drosophila melanogaster line that expresses bacterial $\beta$-galactosidase as a response to stress was used in the present study. ${ }^{20}$ In the said strain of fly the transformation vector is inserted with a P-element, the line contains wild type $h s p 70$ sequence up to the lacZ fusion point. The flies and larvae were cultured on standard Drosophila food containing agar, cornmeal, sugar, and yeast at $24 \pm 1^{\circ} \mathrm{C} .20$

\section{Experimental design}

$\mathrm{CP}$ at 0.025 and $0.050 \mu \mathrm{L} / \mathrm{mL}$ of food concentration alone and with $1,5,10 \mu \mathrm{g} / \mathrm{mL}$ of curcumin were established. The third instar larvae were allowed to feed on them for different durations (12, 24 and $48 \mathrm{~h})$.

\section{Soluble O-nitrophenyl- $\beta$ - galactopyranoside (ONPG) assay}

The expression of $h s p 70$ gives the measure of cytotoxicity. ${ }^{21}$ Briefly, after washing the larvae in phosphate buffer, the larvae were taken in micro centrifuge tube (20 larvae/tube; 5 replicates/group), permeabilized for $10 \mathrm{~min}$ in acetone and incubated overnight at $37^{\circ} \mathrm{C}$ in $600 \mu \mathrm{L}$ of $\mathrm{ONPG}$ staining buffer. Following incubation, the reaction was stopped by adding $300 \mu \mathrm{L} \mathrm{Na}_{2} \mathrm{CO}_{3}$. The extent of reaction was quantified by measuring the absorbance at 420 nm. ${ }^{20}$

\section{Trypan blue exclusion test}

Trypan blue, a vital dye fails to exclude blue staining in dead or dying cells and gives a reli-
Correspondence: Yasir Hasan Siddique, Department of Zoology, Section of Genetics, Faculty of Life Sciences, Drosophila Transgenic Laboratory, Aligarh Muslim University, Aligarh 202002 (U.P.), India.

E-mail: yasir_hasansiddique@rediffmail.com

Key words: Curcumin, Cyclophosphamide, $h s p 70$, Drosophila melanogaster (hsp70-lacZ) Bg9 .

Acknowledgements: I am thankful to the Chairman, Department of Zoology for providing laboratory facilities. I am also thankful to Dr. D. Kar Chowdhuri, Scientist F \& Head Embryo Toxicology, IITR, Lucknow, UP, India for providing $\mathrm{Bg}^{9}$ Drosophila strain.

Received for publication: 31 July 2011

Revision received: 8 0ctober 2011.

Accepted for publication: 23 December 2011.

This work is licensed under a Creative Commons Attribution NonCommercial 3.0 License (CC BYNC 3.0).

(C) Copyright Y.H. Siddique., 2012

Licensee PAGEPress, Italy

Alternative Medicine Studies 2012; 2:e2

doi:10.4081/ams.2012.e2

able measure of tissue damage. The extent of the tissue damage in larvae by the exposure of different concentrations of $\mathrm{CP}$ alone and in combination with different doses of curcumin (1, 5 and $10 \mu \mathrm{g} / \mathrm{mL}$ ) was assayed by a dye exclusion test. ${ }^{22}$ Briefly, the internal tissues of larvae were explanted in a drop of phosphate buffer (PB), rotated in trypan blue stain for 30 min, washed thoroughly in PB and scored immediately for dark blue staining. Total 50 larvae per treatment (10 larvae per dose; 5 replicates per group) were scored for the trypan blue staining on an average composite index per larvae; no color, 0 ; any blue 1; darkly stained nuclei, 2 ; large patches of darkly stained cells, 3 ; or complete staining of most cells in the tissue, 4.22

\section{Statistical analysis}

Statistical analysis was carried out by one way analysis of variance (ANOVA) using commercial Software Statistica Soft Inc (2007).

\section{Results}

The results of the present study reveals that the exposure of 0.025 and $0.050 \mu \mathrm{L} / \mathrm{mL}$ of $\mathrm{CP}$ to the third instar larvae of transgenic Drosophila melanogaster ( $h s p 70-l a c Z$ ) Bg ${ }^{9}$ for the duration of 12,24 and $48 \mathrm{~h}$ showed an increase in the expression of $h s p 70$ (Table 1). The exposure of the third instar larvae to $0.025 \mu \mathrm{L} / \mathrm{mL}$ of $\mathrm{CP}$ 
along with 1, 5 and $10 \mu \mathrm{L} / \mathrm{mL}$ of curcumin for $12 \mathrm{~h}$ results in the reduction of the expression of hsp70 (Table 1). Similar results were obtained for 24 and $48 \mathrm{~h}$ of exposure (Table 1). Similarly, the exposure of third instar larvae to $0.050 \mu \mathrm{L} / \mathrm{mL}$ of $\mathrm{CP}$ along with 1,5 and 10 $\mu \mathrm{g} / \mathrm{mL}$ of curcumin for 12,24 and $48 \mathrm{~h}$ respectively, results in the reduction in the expression of $h s p 70$. The regression analysis was also performed to study the dose effects of curcumin on the $h s p 70$ expression induced by 0.025 and $0.050 \mu \mathrm{L} / \mathrm{mL}$ of CP for the exposure to different durations (Table 2). The exposure of third instar larvae for $12 \mathrm{~h}$ to $0.025 \mu \mathrm{L} / \mathrm{mL}$ of $\mathrm{CP}$ along with 1,5 and $10 \mu \mathrm{g} / \mathrm{mL}$ of curcumin was associated with the $\beta$-coefficient of -0.97 $(\mathrm{F}=15.446)$ (Table 2). For 24 and $48 \mathrm{~h}$ of exposures the $\beta$-coefficient values were -1.0 $(\mathrm{F}=177.96)$ and $-1.0(\mathrm{~F}=2375.11)$, respectively (Table 2). The reduction in the value of $\beta$-coefficient demonstrates the reduction in the $\beta$ galactosidase activity. The exposure of third instar larvae to $0.050 \mu \mathrm{L} / \mathrm{mL}$ of $\mathrm{CP}$ along with 1 , 5 and $10 \mu \mathrm{g} / \mathrm{mL}$ of curcumin was associated with the $\beta$-coefficient values of -0.98 $(\mathrm{F}=23.24), \quad-0.99 \quad(\mathrm{~F}=79.48)$ and -0.98 $(\mathrm{F}=22.73)$ for 12,24 and $48 \mathrm{~h}$ of exposure, respectively (Table 2). Trypan blue staining was performed to study the tissue damage induced by 0.025 and $0.050 \mu \mathrm{L} / \mathrm{mL}$ of $\mathrm{CP}$ alone and in combination with different doses of curcumin $(1,5$ and $10 \mu \mathrm{g} / \mathrm{mL})$ for different durations of exposure. About $95 \%$ of the larvae of untreated were negative to trypan blue staining even after $48 \mathrm{~h}$ except for light staining in the head region (Figure 1A). The target tissues were similar in the both treatments i.e. 0.025 and $0.050 \mu \mathrm{L} / \mathrm{mL}$ of $\mathrm{CP}$ only the intensity of staining was different. The exposure of 0.025 and $0.050 \mu \mathrm{L} / \mathrm{mL}$ of $\mathrm{CP}$ for $12 \mathrm{~h}$ results in the tissue damage of $90 \%$ of larvae in the mid gut, hind gut, malpighian tubules and brain ganglia (Figure 1B). The exposure of 0.025 and 0.050 $\mu \mathrm{L} / \mathrm{mL}$ of $\mathrm{CP}$ for $24 \mathrm{~h}$ results tissue damage in the brain ganglia, salivary glands, gastric caecae, mid gut, hind gut and malpighian tubules of about $95 \%$ of the larvae (Figure 1C). The exposure of 0.025 and $0.050 \mu \mathrm{L} / \mathrm{mL}$ of CP to 48 $h$ results in the tissue damage of about $95 \%$ of the larvae in brain ganglia, salivary glands, gastric caecae, proventriculus fore gut, mid gut, hind gut and malpighian tubules (Figure 1D). The exposure of larvae to 0.025 and 0.050 $\mu \mathrm{L} / \mathrm{mL}$ of $\mathrm{CP}$ along with various doses of curcumin results in the reduction of the tissue damage as the dose of curcumin was

Table 1. $\beta$-galactosidase activity measured in transgenic Drosophila melanogaster (bsp70lac $Z$ ) $B g$ 9 third instar larvae exposed to different concentrations of cyclophosphamide and curcumin for various durations.

\begin{tabular}{lccc} 
Treatments & $\begin{array}{c}\text { O.D. }(\text { Mean } \pm \text { SE) } \\
\text { after } 12 \text { h }\end{array}$ & $\begin{array}{c}\text { O.D. (Mean } \pm \text { SE) } \\
\text { after } 24 \text { h }\end{array}$ & $\begin{array}{c}\text { O.D. (Mean } \pm \text { SE) } \\
\text { after } 48 \text { h }\end{array}$ \\
CP $(\mu \mathrm{L} / \mathrm{mL})$ & & & \\
0.025 & $0.2483 \pm 0.0111^{*}$ & $0.2684 \pm 0.0132^{*}$ & $0.2793 \pm 0.0164^{*}$ \\
0.050 & $0.2553 \pm 0.0122^{*}$ & $0.2783 \pm 0.0149^{*}$ & $0.2868 \pm 0.0183^{*}$ \\
$\mathrm{CP}(\mu \mathrm{L} / \mathrm{mL})+$ Curcumin $(\mu \mathrm{g} / \mathrm{mL})$ & & & \\
$0.025+1$ & $0.2301 \pm 0.0096^{* \circ}$ & $0.2493 \pm 0.0131^{* \circ}$ & $0.2541 \pm 0.0114^{* \circ}$ \\
$0.025+5$ & $0.2283 \pm 0.0092^{\circ}$ & $0.2411 \pm 0.0103^{* \circ}$ & $0.2443 \pm 0.0101^{* \circ}$ \\
$0.025+10$ & $0.2219 \pm 0.0086^{\circ}$ & $0.2332 \pm 0.0086^{* \circ}$ & $0.2329 \pm 0.093^{* \circ}$ \\
$0.050+1$ & $0.2311 \pm 0.0087^{* \circ}$ & $0.2539 \pm 0.0116^{* \circ}$ & $0.2634 \pm 0.0128^{* \circ}$ \\
$0.050+5$ & $0.2250 \pm 0.0073^{\circ}$ & $0.2421 \pm 0.0109^{* \circ}$ & $0.2501 \pm 0.0106^{* \circ}$ \\
$0.050+10$ & $0.2213 \pm 0.0070^{\circ}$ & $0.2321 \pm 0.0067^{* \circ}$ & $0.2415 \pm 0.0109^{* \circ}$ \\
\hline Curcumin $(\mu \mathrm{g} / \mathrm{mL})$ & & & \\
1 & $0.2138 \pm 0.0098$ & $0.2234 \pm 0.0068$ & $0.2243 \pm 0.0057$ \\
5 & $0.2212 \pm 0.0053$ & $0.2273 \pm 0.0078$ & $0.2238 \pm 0.0063$ \\
10 & $0.2219 \pm 0.0074$ & $0.2293 \pm 0.0089$ & $0.2268 \pm 0.0082$ \\
Control & $0.2122 \pm 0.0083$ & $0.2133 \pm 0.0043$ & $0.2136 \pm 0.0058$
\end{tabular}

$\mathrm{CP}$, Cyclophosphamide; OD, optical density; SE, standard error. *Significant at $\mathrm{P}<0.005$ compared to untreated; ${ }^{\circ}$ Significant at $\mathrm{P}<0.005 \mathrm{com}$ pared to CP treatment.

Table 2. Regression analysis for the dose effect of curcumin along with 0.025 and $0.050 \mu \mathrm{L} / \mathrm{mL}$ of cyclophosphamide for various duration of exposure.

\begin{tabular}{lccccccccc} 
S. No. & $\begin{array}{c}\text { Treatments } \\
\text { CP }(\mu / / m L)\end{array}$ & $\begin{array}{c}\text { Duration } \\
(\mathrm{h})\end{array}$ & Regression equation & r-value & $\beta$-coefficient & SE & P-value & F-value \\
\hline 1. & 0.025 & 12 & $\mathrm{Y}=0.23171-0.0009 \mathrm{X}$ & -0.9691 & -0.97 & 0.00152 & $<0.0042$ & 15.44 \\
2. & 0.025 & 24 & $\mathrm{Y}=0.25070-0.0018 \mathrm{X}$ & -0.9972 & -1.0 & 0.000864 & $<0.0022$ & 177.96 \\
\hline 3. & 0.025 & 48 & $\mathrm{Y}=0.25631-0.0024 \mathrm{X}$ & -0.9998 & -1.0 & 0.00030 & $<0.0008$ & 2375.11 \\
4. & 0.050 & 12 & $\mathrm{Y}=0.23153-0.0011 \mathrm{X}$ & -0.9792 & -0.98 & 0.00144 & $<0.0040$ & 23.24 \\
\hline 5. & 0.050 & 24 & $\mathrm{Y}=0.25553-0.0024 \mathrm{X}$ & -0.9938 & -0.99 & 0.00174 & $<0.0044$ & 79.48 \\
6. & 0.050 & 48 & $\mathrm{Y}=0.26432-0.0023 \mathrm{X}$ & -0.9787 & -0.98 & 0.00317 & $<0.0076$ & 22.73 \\
\hline
\end{tabular}

CP, cyclophosphamide; SE, standard error.

increased. The exposure of larvae to 0.050 $\mu \mathrm{L} / \mathrm{mL}$ of CP along with 1,5 and $10 \mu \mathrm{g} / \mathrm{mL}$ of curcumin for $48 \mathrm{~h}$ results in the reduction of tissue damage of about $75 \%$ of larvae.

\section{Discussion}

The results of the present study reveal that the curcumin is potent in reducing the toxic effects induced by CP. D. melanogaster is a well established model for the study of antigenotoxic effects of different compounds and mixtures due to its well documented genetics and developmental biology. ${ }^{23-26} \mathrm{D}$. melanogaster is also capable activating promutagens and procarcinogens. ${ }^{27}$ The metabolite of CP is phosphoramide mustard. 28 It forms DNA cross links between and within DNA strands of guanine N-7 positions that heads to the cell death. ${ }^{29}$ The higher doses of CP are associated with cytotoxicity. ${ }^{28}$ Curcumin has a protective role against various mutagenic agents but the higher doses of curcumin are also cytotoxic. ${ }^{11}$ In the present study the curcumin reduced the toxic effects of CP. The study of the anticancer drugs is of special significant due to the possibility that they may induce secondary tumors in cancer patients. ${ }^{30}$ In several studies, the flavonoids have been found to be very protective against chemotherapy toxicity. ${ }^{31}$ According to National Toxicological Programme guidelines development and validation of alternative models is necessary to get reliable and sensitive results. For traditional toxicological studies a shift for the use of animal models has been taken place to alternative models and in silico approaches to avoid animal experimentation. ${ }^{32}$ Drosophila has a lot of similarities with human genome and is easy to handle, culture and ethical problems are less with this model. Drosophila as a model in pharmaceutical research is time efficient and cost effective in comparison to rodents. In future Drosophila will be used to detect adverse drug reactions. It will be helpful in reducing time and cost in the field of drug development process. ${ }^{33}$ Mid gut tissues of insects have the highest concentration of cytochrome species and high microso- 
mal oxidase activity. ${ }^{34}$ In the present study the damage is first observed in the mid gut tissues, probably the metabolic activation of $\mathrm{CP}$ takes place in the mid gut. The addition of curcumin results in the reduction of $h s p 70$ expression and tissue damage. This may be due to
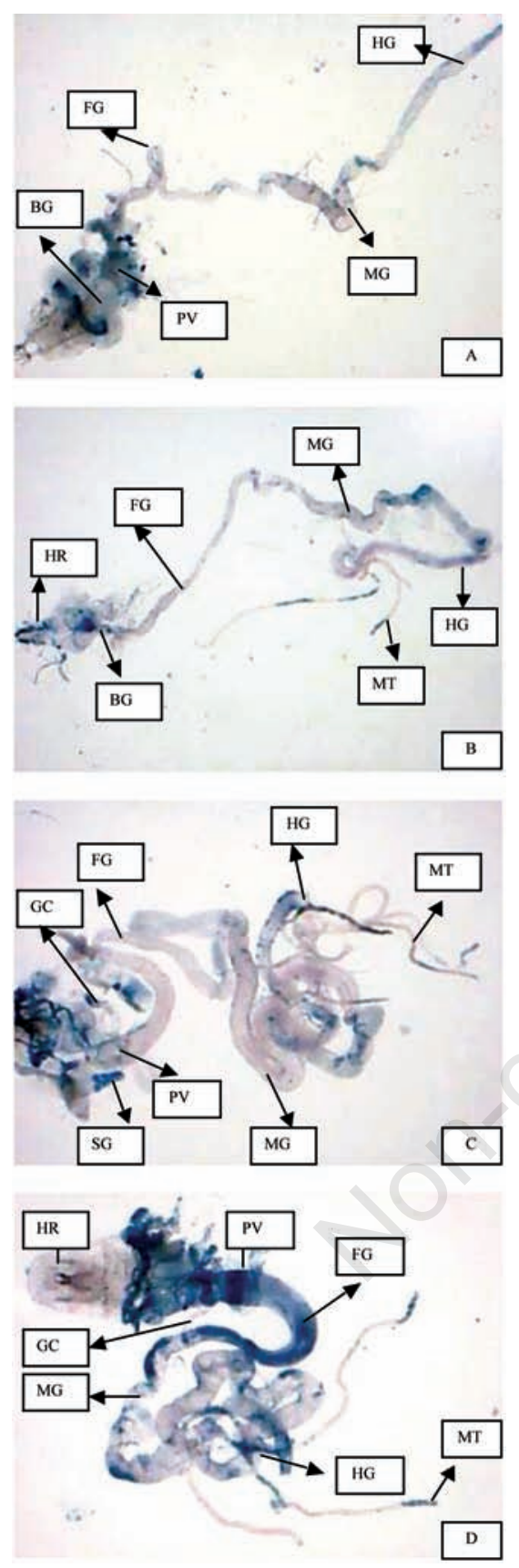

Figure 1. A) to D) show the Trypan blue staining in the third instar larvae of transgenic Drosophila melanogaster (bsp70lac $Z) B g^{9}$ exposed to $0.050 \mu 1 / \mathrm{mL}$ of cyclophosphamide for $12 \mathrm{~h}(\mathrm{~B}), 24 \mathrm{~h}$ (C), $48 \mathrm{~h}$ (D) and control (A). HR, head region; BG, brain ganglia; PV, proventriculus; SG, salivary gland; GC, gastric caecae; FG, fore gut; MG, mid gut; HG, hind gut; $M T$, malpighian tubule. the possible prevention of metabolic activation of cyclophosphamide by curcumin. 35 The lower doses of chemotherapeutic agents when combined with selected antioxidants, could be used to obtain the same killing power as higher doses of the agent. Unlike, using higher dose of chemotherapeutic agents the enhanced efficiency mixture would be expected to reduce significantly for the complications associated to reduce significantly for the complications associated with chemotherapeutic agents. $^{36}$ The results of the present study showed that the selected doses of curcumin reduce the toxic effects of $\mathrm{CP}$, and also supports the promotion of the use of alternative to higher laboratory animals such as mice/rats for the initial screening of the chemical agents for their possible toxic or protective effects.

\section{References}

1. Ren S, Kalhorn TF, McDonald GB, et al. Pharmacokinetics of cyclophosphamide and its metabolites in bone marrow transplantation patients. Pharm Drug Disp 1998;64:289-301.

2. Shanafelt TD, Lin T, Geyer SM, et al. Pentostatin, cyclophosphamide, and rituximab regimen in older patients with chronic lymphocytic leukemia. Cancer 2007;109:2291-8.

3. Young SD, Whissell M, Noble JCS, et al. Phase-II clinical trial results involving treatment with low-dose daily oral cyclophosphamide, weekly vinblastine, and rofecoxib in patients with advanced solid tumors. Clin Can Res 2006;12:3092-8.

4. Scott DGI, Bacon P. Intravenous cyclophosphamide plus methylprednisolone in treatment of systemic rheumatoid vasculitis. The Amer J Med 1984;76:377-84.

5. Hoffman GC, Leavitt RY, Fleisher TA, et al. Treatment of Wegener's granulomatosis with intermittent high dose intravenous cyclophosphamide. The Amer J Med 1990;89:403-10.

6. Nover L. Heat shock response of eukaryotic cells. Berlin; Springerverlag, 1994.

7. Nover L. The heat shock response. Boca Raton, FL: CRC Press, 1991;5:344.

8. Bierkens JGEA. Applications and pitfalls of stress proteins in biomonitoring. Toxicology 2000;153:61-72.

9. Mukhopadhyay I, Saxena DK, Chowdhuri DK. Hazardous effects of effluent from the chrome plating industry: $70 \mathrm{kDa}$ heat shock protein expression as a marker of cellular damage in transgenic Drosophila melanogaster (hsp70-lacZ)Bg9 . Environ Health Persp 2003;3:1926-32.

10. Mukhopadhyay I, Nazir A, Mahmood K, et al. Toxicity of orgemone oil: Effect on hsp70 expression and tissue damage in transgenic Drosophila melanogaster (hsp 70-lacZ)Bg9 . Cell Biol Toxicol 2002;18:1-11.

11. Irulappan R, Natarajan P. Antimutagenic potential of curcumin on chromosomal aberrations in Allium cepa. J Zhejiang Univ Sci B 2007;8:470-5.

12. Chattopadhyay J, Biswas K, Bandyopadhyay V, Banerjee RK. Turmeric and curcumin: biological actions and medicinal applications. Curr Sci 2004;87:44-53.

13. Siddique YH, Ara G, Beg T, et al. Assessment of cell viability, lipid peroxidation and quantification of DNA fragmentation after the treatment of anticancerous drug Miotomycin $\mathrm{C}$ and curcumin in cultured human blood lymphocytes. Exp Tox Pathol 2010;62:503-8.

14. Siddique YH, Ara G, Beg T, Afzal M. Protective effect of curcumin against the genotoxic damage induced by tinidazole in cultured human lymphocytes. Acta Pharm Sci 2010;52:23-30.

15. Siddique YH, Ara G, Beg T, Afzal M. Protective effect of curcumin against chlormadinone acetate induced genotoxic damage in cultured human peripheral blood lymphocytes. Pharmacology online 2010;3:644-50.

16. Siddique YH, Ara G, Gupta J, et al. Protective effect of curcumin against hydrogen peroxide induced genotoxic damage in cultured human lymphocytes. Res J Biotechnol 2008;3:390-2.

17. Benford DJ, Hanley AB, Bottrill K, et al. Biomarkers as predictive tools in toxicity testing. The report and recommendations of EVCAM workshop. Alt Lab Anim 2000;28:119-31.

18. Festing MFW, Baumans V, Combes DR, et al. Reducing the use of laboratory animals in biomedical research: problems and possible solutions. Alt Lab Anim 1998;26:283301.

19. Siddique YH, Ara G, Afzal M. Effect of cyclophosphamide on hsp70 expression in transgenic Drosophila melanogaster (hsp70-lacZ)Bg9. Drosophila Info Ser (Accepted).

20. Nazir A, Mukhopadhyay I, Saxena DK, et al. Evaluation of toxic potential of captan: induction of hsp70 and tissue damage in transgenic Drosophila melanogaster (hsp70-lacZ)Bg9. J Biochem Mol Toxicol 2003;17:98-107.

21. Chowdhuri DK, Saxena DK, Vishwanathan PN. Effect of hexachlorocyclohexane (HCH), its isomers and metabolites on hsp70 expression in transgenic Drosophila melanogaster. Pesticide Biochem Physiol 1999;63:15-25.

22. Krebs RA, Feder ME. Tissue specific variation in hsp70 expression and thermal damage in Drosophila melanogaster larvae. 
The J Exp Biol 1997;200:2007-15.

23. de sousa NC, de Rezende AAA, de silva RMG, et al. Modulatory effects of Tabebuia impetiginosa (Lamiales, Bignoniaceae) on doxorubicin induced somatic mutation and recombination in Drosophila melanogaster. Genet Mol Biol 2009;32:382-8.

24. Castro AJS, Grisolia CK, de Araujo BC, et al. Recombinogenic effects of the aqueous extract of pulp from pegui fruit (Caryocar brasiliense) on somatic cell of Drosophila melanogaster. Genet Mol Res 2008;7:137583.

25. Ahmed ES, Twaty NH, Fakiha KG, et al. Mutagenic and antimutagenic effects of some plant extracts in Drosophila melanogaster. Nature Sci 2010;8:77-82.

26. Siddique YH, Ara G, Faisal M, et al. Protective role of Plumbago zeylanica extract against the toxic effects of ethinylestradiol in the third instar larvae of transgenic Drosophila melanogaster (hsp70-lacZ)Bg9 and cultured human peripheral blood lymphocytes. Alternative
Med Studies 2011;1:e7.

27. Serikaya R, Cakir S. Genotoxicity testing of four food preservatives and their combination in the Drosophihla Wing Spot Test. Environ Tox Pharm 2005;20: 424-30.

28. Halsens BF. Comparison of the mutagenicity and teratogenicity of cyclophosphamide and its metabolites, 4-hydroxy cyclophosphamide, phosphoramide mustard, and acrolein. Cancer Res 1982;42:3016-21.

29. Benson AJ, Martin CN, Garner RC. N-(2hydroxyethyl)-N-[2-(7- guaninyl) ethyl] amine, the putative major DNA adducts of cyclophosphamide in vitro and in vivo in the rat. Biochem Pharmacol 1988;37:297985 .

30. Aydemir N, Celikler S, Bilalouglu R. In vitro genotoxic effects of the anticancer drug genicitabine in human lymphocytes. Mutat Res 2005;582:35-41.

31. Siddique YH, Beg T, Afzal M. Antigenotoxic effect of apigenin against anticancerous drugs. Toxicol in vitro 2008;22:625-31.

32. AMBR. International Symposium on alter- nate animal models in biological research: present and future perspectives in toxicology, 2010, October 29-31, IITR, Lucknow, India.

33. Avanesian A, Semmani S, Jafri M. Can Drosophila melanogaster represent a model system the detection of reproductive adverse drug reactions? Drug Dis Today 2009;14:761-6.

34. Wilkinson CF, Brattsten. Microsomal drug metabolizing enzymes in insects. Drug Metab Rev 1992;1:153-228.

35. Noel S, Kasinathan M, Rath SK. Evaluation of epigenin using in vitro cytochalasin blocked micronucleus assay. Toxicol in vitro 2006;20:1168-72.

36. Blaylock RL. A review of conventional cancer prevention and treatment and the adjunctive use of nutraceutical supplements and antioxidants: is there a danger or a significant benefit. J American Nutr Assoc 2000;3:75-95. 